\title{
ENGLISH VERSION: ANALYSIS OF ASSOCIATION BETWEEN THE POLYMORPHIC VARIANTS OF THE TLR2 (RS5743708) AND TLR4 (RS4986790, RS4986791) GENES WITH THE HEALTH STATUS OF APPARENTLY HEALTHY INDIVIDUALS*
}

Izmailova O.V.

Higher State Educational Establishment of Ukraine «Ukrainian Medical Stomatological Academy», Poltava, Ukraine

The study of single-nucleotide polymorphisms of Toll-like receptors has an important applied and theoretical value for revealing the mechanisms in formation of immunity features and its correction. The aim of the research was to study the available frequency of polymorphic variants of the TLR2 gene (rs5743708) and 896A/G (rs4986790), 1196C/T (rs4986791) of the TLR4 gene, and to assess the association with the health status of apparently healthy individuals. Materials and methods: the study involved 114 Caucasian individuals living in Poltava or Poltava oblast for a minimum of 2 years, who underwent the collection of anamnestic data, as well as the data of objective and clinical examinations. The polymorphic sites of the TLR2 (rs5743708) and TLR4 genes (rs4986790, rs4986791) were determined by polymerase chain reaction $(P C R)$ followed by analysis of the restriction fragments length of the $P C R$ products. The results of distribution of polymorphic variants 2258G/A in the genotypes of the TLR2 gene (rs5743708), 896A/G of the TLR4 gene (rs4986790), and 1196C/T of the TLR4 gene (rs4986791) corresponded to the theoretically expected ones at the HardyWeinberg equilibrium $\left(X^{2}=0.02, p=0.99 ; X^{2}=0.29, p=0.86 ; X^{2}=1.46, p=0.48\right.$, respectively). When comparing the presence of individual clinical manifestations that were detected during the interviewing, with the presence of polymorphic alleles in the genotype, a reliable relationship was established between the presence of the $A$ allele in the polymorphic version of the TLR2 gene (rs5743708) in the genotype with rheumatism $(p=0.05)$, pyelonephritis ( $p=$ $0.05)$ and a bad habit of smoking $(p=0.04)$.

Key words: TLR, single nucleotide polymorphism, genotype, ligand, state of health

Toll-like receptors (TLRs) belong to the class of transmembrane single-chain signal receptor proteins that recognize foreign evolutionarily conservative molecular structures of pathogens, known as pathogen-associated molecular structures and trigger the cascade of sequential reactions of congenital and antigen-specific adaptive immunity through signaling pathways (MyD88-dependent and TRIF-dependent), resulting in the expression of genes of proinflammatory cytokines and modulation of the inflammatory response of the body [1].

A large number of research publications covering the problem of recognizing foreign pathogens prove the leading role of TLRs in this issue, but sometimes contain controversial data regarding the influence of polymorphic variants of genes encoding these receptors on the recognition of the corresponding ligands and the intensity of the immune response [2]. Genetic variability of TLRs can determine the differences in the susceptibility of organisms to bacteria and viruses, the intensity of the inflammatory process [3].

The results of studies, conducted by a group of researchers, confirmed the role of polymorphic variants of the TLR2 and TLR4 genes in the sensitivity to infections and aggravated course of such diseases as atopic dermatitis with a predisposition to frequent acute respiratory viral infections [4], atopic bronchial asthma [5], urogenital diseases [6], atherosclerosis [7].

At the same time, the association between the presence of polymorphic alleles in 2258A genotype of the TLR2 gene and $896 \mathrm{G}$ of the TLR4 gene with the development of allergic rhinitis has not been established [8].

Functional polymorphism of the TLR genes, associated with replacement of single nucleotides (single nucleotide polymorphism - SNP). The TLR2 gene is localized on the long shoulder of the 4th chromosome (4q32). In the allelic variant of rs5743708 (2258G/A) of the TLR2 gene, there is a replacement of arginine (Arg) with glutamine (GIn) at position 753 of the polypeptide chain. This leads to confirmatory changes in the TIR domain (the in- tracellular part of the receptor), resulting in the loss of the ability to bind intracellular adapter molecules to this domain, the transmission of signal from the receptor is disrupted, the synthesis of proinflammatory cytokines and the susceptibility to pathogens of infectious diseases are increased $[9,10]$.

The TLR4 gene is localized on the short shoulder of the 9th chromosome (9q33.1). The most studied are two non-synonymic allelic variants of the TLR4 gene, localized in the extracellular domain of the receptor: rs4986790 (896A/G), which causes the aspartic acid to be replaced with glycine in exon 3 at position 299 of the polypeptide chain and rs4986791 (1196C/T), the replacement of tyrosine with isoleucine in position 399. These SNP result in the disruption of the receptor interaction with ligands, which leads to the reduction of the immune response $[10,11]$.

The aim of the present research was to study the available frequency of polymorphic variants $2258 \mathrm{G} / \mathrm{A}$ of the TLR2 gene (rs5743708) 896A/G (rs4986790), and $1196 \mathrm{C} / \mathrm{T}$ (rs4986791) of the TLR4 gene, and to assess the association with the health status of apparently healthy individuals.

This study was conducted in accordance with the plan of research work of Higher State Educational Establishment of Ukraine «Ukrainian Medical Stomatological Academy" «Determining the role of polymorphism of Tolllike receptors in the mechanisms of development of immune-mediated diseases», the state registration number 01090001629.

\section{Materials and methods of research}

The formed group consisted of 114 Caucasian men who had lived in Poltava or Poltava oblast for at least 2 years: $25(21.9 \%)$ people indicated their place of birth in Poltava or Poltava oblast, $83(72.8 \%)$ individuals were born in other regions of Ukraine and $6(5.3 \%)$ respondents were born in another country, although they live permanently in the territory of Ukraine. The group was

\footnotetext{
* To cite this English version: O.V. Izmailova Analysis of association between the polymorphic variants of the TLR2 (rs5743708) and TLR4 (rs4986790, rs4986791) genes with the health status of apparently healthy individuals. // Problemy ekologii ta medytsyny. - 2018. Vol 22, № 1-2. - P. 17-22.
} 
balanced by age and gender: males - 51 (44.7\%), females - $63(55.3 \%)$. The average age of the subjects was $22.56 \pm 9.58$ years.

Collection of anamnestic data, as well as clinical data at the time of examination and objective data on the part of various organs and systems, was conducted at the Department of Internal Medicine No. 3 with Phthisiology. The received data was entered into the observation card of the participant of the study, which was originally developed by the staff of the Department of Clinical Immunology and Allergology of Danylo Halytskyi National Medical University of Lviv.

Determining the polymorphic sites of genes was carried out on the basis of the Research Institute of Genetic and Immunological Foundations of the Development of Pathology and Pharmacogenetics of Higher State Educational Establishment of Ukraine «Ukrainian Medical Stomatological Academy».

All studies were conducted with the permission of the Ethics and Bioethics Committee; before the study, all volunteers signed a written consent to participate in the scientific experiment.

The capillary blood was the material for the study. The isolation of genomic DNA from blood lymphocytes was carried out using the DNA-Express test system in accordance with the recommendations of the manufacturer (NPF "Litech", Russia).

Identifying the alleles of polymorphic sites of TLR2 (rs5743708) and TLR4 gene (rs4986790, rs4986791) was carried out by polymerase chain reaction (PCR) followed by analysis of restriction fragment length of PCR products. The sequence of specific oligonucleotide primers which are synthesized NGO "SybEnzym" (Russia), temperature settings accession primers, restriction endonuclease (Scientific and Production Association "SibEnzim", Russia) taken from the scientific literature [12, 13].

The statistical analysis of the data was performed on a personal computer using the STATISTICA for Windows 6.0 (StatSoft Inc., USA) and MS Excel spreadsheets. The genotypic distribution of the studied polymorphic loci was checked for compliance with the Hardy-Weinberg equation (PCV) using the $\mathrm{x} 2$ criterion for degrees of freedom equal to $2(\mathrm{df}=2)$. The exact two-sided Fischer criterion (for small groups) was used to assess the validity of the differences between the groups. Statistically significant differences were considered at $p<0.05$.

\section{Results and discussion}

We analyzed the data obtained through interviews and standard examination.

It was revealed that $7(6.1 \%)$ respondents previously lived in the polluted area due to Chernobyl accident, and $5(4.4 \%)$ had parents from the area of Chernobyl nuclear power plant. Furthermore, $7(6.1 \%)$ people indicated alcohol abuse and 33 of them $(28.9 \%)$ were smokers.

In the collection of anamnesis, a complicated heredity with endocrine diseases was detected in $12(10.5 \%)$ people, with allergic diseases in $12(10.5 \%)$ people, in 6 $(5.3 \%)$ respondents the immediate family had oncological disease in the anamnesis, $2(1.8 \%)$ respondents indicated the presence of neurological pathology in their parents, the presence of diffuse connective tissue diseases
- $1(0.9 \%)$ person. $81(71.0 \%)$ people reported no hereditary predisposition to various diseases.

According to the maternal line, we detected such diseases as hypertension and varix dilatation of the lower limbs (indicated by 1 person), Parkinson's disease (indicated by 1 person), thyroid disease (indicated by 1 person), stroke (indicated by 1 person), tuberculosis (indicated 1 person), bronchial asthma (indicated by 1 person), oncological diseases (indicated by 1 person). According to the paternal line, we detected: hypertension (indicated by 5 people), varix dilatation of the lower limbs (indicated by 1 person), diabetes mellitus (indicated by 3 respondents), Botkin's disease (indicated by 2 people), cancer (indicated by 4 respondents), tuberculosis (indicated by 2 people), ectodermal dysplasia (indicated by 1 person).

The data of the epidemiological history indicate the incidence of acute respiratory diseases: once a year -29 $(25.4 \%)$ of the examined respondents, twice a year -33 $(28.9 \%)$ of respondents, from 3 to 5 times a year -13 (11.4\%) people and more than 5 times a year - only 2 respondents $(1.8 \%)$.

Among the infections that had been transmitted earlier, chicken pox was prevalent - $64(56.1 \%)$ respondents, rubella - $29(25.4 \%)$, herpes infections - 12 $(10.5 \%)$, measles and infections of the gastrointestinal tract $-10(8.8 \%)$, as well as $8(7.0 \%)$ people with past cutaneous fungal infections, $7(6.1 \%)$ people reported having had a history of pertussis and parotitis, $3(2.6 \%)$ respondents - infectious hepatitis and bacterial skin infections, $2(1.8 \%)$ - scarlet fever, rheumatism, urogenital infections and genital herpes, in addition, diphtheria, poliomyelitis, infectious mononucleosis, tuberculosis and neuroinfections were reported by $1(0.9 \%)$ person each.

The structure of diseases of the skin and mucous membranes in this group was represented by hives -6 $(5.3 \%)$ of all interviewed individual, $4(3.5 \%)$ respondents - with dermatitis, $9(7.9 \%)$ - with hyperpigmentation and purpura $-1(0.9 \%)$ person.

Among the diseases of the urinary system there were cystitis - $9(7.9 \%)$, enuresis and pyelonephritis - 2 $(1.8 \%)$ respondents.

One of the promising directions for studying the genetic predisposition to the development and / or characteristics of the course of immunoregulatory diseases is the establishment of allelic variants of the genes of the innate immune receptors, since the search for genetic markers is the basis of personalized medicine, which allows predicting the susceptibility to disease, its course, as well as the development of individual preventive and therapeutic measures based on the use of immunomodulators - agonists or antagonists of TLRs.

The next step in our research was to study the frequency of occurrence and compliance in distribution of the genotypes of the $2258 \mathrm{G} / \mathrm{A}$ polymorphic variants of the TLR2 (rs5743708) and 896A/G (rs4986790), 1196C/T (rs4986791) of the TLR4 gene with the Hardy-Weinberg equation in the study group.

Table 1 presents the inter-group analysis of the distribution of genotypes and alleles of the polymorphic variants 2258G/A TLR2 (rs5743708) and 896A/G (rs4986790), 1196C/T (rs4986791) of the TLR4 gene. 
The inter-group analysis of the frequency distribution of genotypes and alleles of the polymorphic variants $2258 \mathrm{G} / \mathrm{A}$ gene of TLR2 (rs5743708) and 896A/G (rs4986790), 1196C/T (rs4986791) of the TLR4 gene

\begin{tabular}{|c|c|c|c|c|c|c|c|}
\hline \multirow[t]{2}{*}{ Genotypes } & \multicolumn{2}{|c|}{ Genotypes distribution } & \multicolumn{2}{|c|}{$\begin{array}{c}\text { Comparison } \\
\text { of observed frequen- } \\
\text { cies of genotypes } \\
\text { with the expected } \\
\text { ones }(\mathrm{df}=2)\end{array}$} & \multirow[t]{2}{*}{$\begin{array}{l}\text { Coefficient of } \\
\text { population } \\
\text { inbreeding, F }\end{array}$} & \multirow[t]{2}{*}{$\begin{array}{c}\text { Adequate } \\
\text { consideration } \\
\text { of rare alleles, } \\
\mu\end{array}$} & \multirow[t]{2}{*}{$\begin{array}{l}\text { Part rare } \\
\text { alleles, } \mathrm{h}\end{array}$} \\
\hline & $\begin{array}{l}\text { observed } \\
(n=114)\end{array}$ & expected & $x^{2}$ & $\mathrm{p}$ & & & \\
\hline \multicolumn{8}{|c|}{ The 2258G/A polymorphism of the TLR2 gene } \\
\hline $\begin{array}{l}\text { GG } \\
\text { GA } \\
\mathrm{AA}\end{array}$ & $\begin{array}{c}111(97.37) \\
3(2.63) \\
-\end{array}$ & $\begin{array}{c}111.05 \\
2.93 \\
0.02\end{array}$ & 0.02 & 0.99 & -0.01 & 1.23 & 0.39 \\
\hline \multicolumn{8}{|c|}{ The 896A/G polymorphism of the TLR4 gene } \\
\hline $\begin{array}{l}\text { AA } \\
A G \\
G G\end{array}$ & $\begin{array}{c}103(90.35) \\
11(9.65) \\
-\end{array}$ & $\begin{array}{c}103.32 \\
10.42 \\
0.26\end{array}$ & 0.29 & 0.86 & -0.05 & 1.43 & 0.29 \\
\hline \multicolumn{8}{|c|}{ The $1196 \mathrm{C} / \mathrm{T}$ polymorphism of the TLR4 gene } \\
\hline $\begin{array}{l}\text { CC } \\
\text { CT } \\
\text { TT }\end{array}$ & $\begin{array}{c}103(90.35) \\
10(8.77) \\
1(0.88)\end{array}$ & $\begin{array}{c}102.26 \\
11.40 \\
0.34\end{array}$ & 1.46 & 0.48 & 0.12 & 1.45 & 0.28 \\
\hline
\end{tabular}

The distribution of the genotypes of the polymorphic variant of $2258 \mathrm{G} / \mathrm{A}$ of the TLR2 gene (rs5743708) was as follows: the GG genotype was found in $111(97.37 \%)$ respondents, GA - in $3(2.63 \%)$, the homozygous genotype AA was not detected in any of the subjects. The allele $G$ frequency with this distribution of genotypes was $98.68 \%$, and the allele A frequency was $1.32 \%$.

The data presented at the National Center for Biotechnology Information (NCBI) website indicates that the global allele A of the polymorphic variant of the $2258 \mathrm{G} / \mathrm{A}$ of the TLR2 gene (rs5743708) is negligible and is $0.68 \%$ [14]. Almost the same common frequency of occurrence of $A$ (allele $0.7 \%$ ) is also indicated at the Ensembl website. At the same site, there is information on the frequency distribution of the alleles of the polymorphic variant 2258G/A of the TLR2 gene (rs5743708) in the European population, which is considerably higher than the global one and is $2.4 \%$. The distribution of subpopulations varies considerably, namely: the frequency of the $A$ allele among the Iberian population of Spain is the lowest and is $0.5 \%$, among the population of Tuscany $-1.9 \%$, among the British and Scots $-2.7 \%$, among the Finnish population $-3.0 \%$ [15]. The frequency of the A allele $(1.32 \%)$ obtained by us is almost twice less than the average frequency found in the Europeans population, but also exceeds the global $A$ allele frequency of the $2258 \mathrm{G} / \mathrm{A}$ polymorphic variant of the TLR2 gene (rs5743708).

In calculating the expected frequency of genotypes, the following results were obtained: the calculated frequency of GG genotype was 111.05; GA genotype - 2.93 and AA genotype -0.02 . Such a distribution of genotypes in the group corresponded to that expected at Hardy-Weinberg equilibrium $\left(x^{2}=0.02 ; p=0.99\right)$. Rare allele counting less than $2(\mu=1.23)$ and the proportion of rare alleles above zero $(h=0.39)$ indicate uneven distribution of alleles. The approximation to the equilibrium of the genetic structure of this sample is also evidenced by the population inbreeding rate approaching zero $(\mathrm{F}=-0.01)$.

The analysis of prevalence of polymorphic variant 896A/G of the TLR4 gene (rs4986790) showed that the AA genotype was found in $103(90.35 \%)$ people, AG genotype - in 11 (9.65\%), GG genotype was not found in this group. The allele $A$ frequency was $95.18 \%$, and the allele $G$ frequency was $4.82 \%$. The calculation of the ex- pected frequency of genotypes in the given group showed a coincidence with the observed one and was: AA genotype - 103.32; AG genotype - 10.42; GG genotype -0.26 , which corresponded to the theoretically expected at Hardy-Weinberg equilibrium $\left(x^{2}=0.29 ; p=\right.$ $0.86)$.

In addition, an uneven distribution of alleles was observed, since the rate of inclusion of rare alleles was 1.43 , and the proportion of rare alleles was 0.29 . The inbreeding rate indicated an insignificant heterozygotes deficiency $(F=0.05)$.

The results obtained in studies on the frequency of occurrence of the polymorphic variant $896 \mathrm{~A} / \mathrm{G}$ of the TLR4 gene in other regions of Ukraine among the groups of apparently healthy individuals somewhat differed. Thus, when examining 285 inhabitants of Crimea, AA genotype was detected in $85 \%$ of people, AG genotype in $14 \%$, GG genotype - in $1 \%$ of all respondents [16].

The distribution of the frequencies of genotypes of the polymorphic locus $1196 \mathrm{C} / \mathrm{T}$ of the TLR4 gene (rs4986791) was as follows: the SS genotype was found in $103(90.35 \%)$ people, the ST genotype - in 10 (8.77\%) and the TT genotype - in $1(0.88 \%)$ person. By the frequency of alleles, the distribution was as follows: the $\mathrm{C}$ allele frequency was $94.74 \%$, and the $\mathrm{T}$ allele frequency was $5.26 \%$.

The calculation of the expected frequency of genotypes showed the following results: CC genotype 102.26, CT genotype - 11.40 and TT genotype - 0.34 Such a distribution of genotypes in the group corresponded to that expected at Hardy-Weinberg equilibrium $\left(X^{2}=1.46 ; p=0.48\right)$. Indicators for the inclusion of rare alleles $(\mu=1.45)$ and the proportion of rare alleles $(h=$ 0.28 ) indicate uneven distribution of alleles in this group. The inbreeding rate indicates insufficient heterozygotes in the population and was 0.12 .

Moreover, based on the NCBI and Ensembl data, it is known that the global frequency of $G$ allele in the polymorphic variant $896 \mathrm{~A} / \mathrm{G}$ of the TLR4 gene (rs4986790) is $5.99 \%$, and the global frequency of T allele of the TLR4 (rs4986791) polymorphic variant 1196C/T gene of the TLR4 gene (rs4986790) is $4.07 \%[17,18]$. The prevalence of the $\mathrm{G}$ allele of the polymorphic variant of the TLR4 gene (rs4986790) among the Europeans is on average 5.7\% and varies from $3.7 \%$ - from the Iberian population of Spain to 
$11.6 \%$ - in the population of Finland, in British and Scots this allele is found with a frequency of $4.4 \%$, and Tuscans - with a frequency of $4.7 \%$.

The frequency with which the $T$ allele of the polymorphic variant of the TLR4 gene (rs4986791) is found among Europeans exceeds the global one and is 5.8\%. The distribution by subpopulation also varies greatly and is as follows: the highest frequency of T allele is indicated for the population of Finland $-11.6 \%$, among the Iberians and Tuscans, this allele is found at $4.7 \%$, the lowest frequency is for British and Scots - 3.8\% [19].

The obtained frequencies of $G$ alleles of the polymorphic variant $896 \mathrm{~A} / \mathrm{G}$ of the gene TLR4 (rs4986790) and the T-polymorphic variant $1196 \mathrm{C} / \mathrm{T}$ of the TLR4 gene (rs4986791) are slightly lower than the average frequencies of these alleles among the European population, but did not differ significantly.

Our further study was aimed at comparing the presence of certain clinical manifestations, which were noted during the interviewing, with the presence of the A allele in the genotype (carriers of GA genotype) polymorphic variant of the gene TLR2 (rs5743708) (Table 2).

Table 2 Analysis of clinical signs in the presence of polymorphic variant of the TLR2 gene (rs5743708) in the genotype

\begin{tabular}{|c|c|c|c|c|}
\hline \multicolumn{2}{|l|}{ The presence of the sign } & $\begin{array}{c}\text { Carriers of GG } \\
\text { genotype } \\
(n=111)\end{array}$ & $\begin{array}{c}\text { Carriers of GA } \\
\text { genotype } \\
(n=3)\end{array}$ & $p^{*}$ \\
\hline \multicolumn{2}{|l|}{1} & 2 & 3 & 4 \\
\hline A bad habit of smoking & $\begin{array}{c}\text { yes } \\
\text { no }\end{array}$ & $\begin{array}{l}30 \\
81\end{array}$ & $\begin{array}{l}3 \\
0\end{array}$ & 0.04 \\
\hline Acute respiratory diseases in the anamnesis $-1-2$ times a year & $\begin{array}{c}\text { yes } \\
\text { no }\end{array}$ & $\begin{array}{l}74 \\
37 \\
\end{array}$ & $\begin{array}{l}3 \\
0\end{array}$ & 0.55 \\
\hline Rubeola & $\begin{array}{c}\text { yes } \\
\text { no }\end{array}$ & $\begin{array}{l}27 \\
84 \\
\end{array}$ & $\begin{array}{l}2 \\
1 \\
\end{array}$ & 0.32 \\
\hline Measles & $\begin{array}{c}\text { yes } \\
\text { no }\end{array}$ & $\begin{array}{c}9 \\
102 \\
\end{array}$ & $\begin{array}{l}1 \\
2 \\
\end{array}$ & 0.62 \\
\hline Chicken pox & $\begin{array}{c}\text { yes } \\
\text { no }\end{array}$ & $\begin{array}{l}62 \\
49\end{array}$ & $\begin{array}{l}2 \\
1\end{array}$ & 0.83 \\
\hline Parotitis & $\begin{array}{c}\text { yes } \\
\text { no }\end{array}$ & $\begin{array}{c}6 \\
105 \\
\end{array}$ & $\begin{array}{l}1 \\
2 \\
\end{array}$ & 0.44 \\
\hline Skin viral (herpetic) infections & $\begin{array}{c}\text { yes } \\
\text { no }\end{array}$ & $\begin{array}{c}11 \\
100\end{array}$ & $\begin{array}{l}1 \\
2\end{array}$ & 0.73 \\
\hline Rheumatism & $\begin{array}{c}\text { yes } \\
\text { no }\end{array}$ & $\begin{array}{c}1 \\
110 \\
\end{array}$ & $\begin{array}{l}1 \\
2 \\
\end{array}$ & 0.05 \\
\hline Dermatitis & $\begin{array}{c}\text { yes } \\
\text { no }\end{array}$ & $\begin{array}{c}3 \\
108 \\
\end{array}$ & $\begin{array}{l}1 \\
2 \\
\end{array}$ & 0.21 \\
\hline Pyelonephritis & $\begin{array}{c}\text { yes } \\
\text { no }\end{array}$ & $\begin{array}{c}1 \\
110\end{array}$ & $\begin{array}{l}1 \\
2\end{array}$ & 0.05 \\
\hline
\end{tabular}

It was found that in carriers of the A allele (genotype $\mathrm{GA})$ had significantly more cases of inflammatory diseases associated with bacterial infection, namely rheumatism and pyelonephritis $(p=0.05)$. All three people with the GA genotype of the TLR2 gene (rs5743708) had a bad habit of smoking $(p=0.04)$.
Further, a comparative analysis of existing clinical manifestations with the presence of the $G$ allele in the genotype (carriers of AG genotype) of the polymorphic variant of the TLR4 gene (rs4986790) was performed (Table 3).

Analysis of clinical signs in the presence of polymorphic variant of the TLR4 Table 3

\begin{tabular}{|c|c|c|c|c|}
\hline \multicolumn{2}{|l|}{ The presence of the sign } & \multirow{2}{*}{$\begin{array}{c}\text { Carriers of } A A \\
\text { genotype } \\
(n=105)\end{array}$} & \multirow{2}{*}{$\begin{array}{c}\begin{array}{c}\text { Carriers of } A G \\
\text { genotype } \\
(n=9)\end{array} \\
1 \\
8 \\
\end{array}$} & \multirow{2}{*}{$\frac{p^{*}}{0.86}$} \\
\hline Parents from the area of Chernobyl nuclear power plant & $\begin{array}{c}\text { yes } \\
\text { no }\end{array}$ & & & \\
\hline A bad habit of smoking & $\begin{array}{c}\text { yes } \\
\text { no }\end{array}$ & $\begin{array}{l}31 \\
74\end{array}$ & $\begin{array}{l}2 \\
7\end{array}$ & 0.94 \\
\hline The presence of endocrine diseases in close relatives & $\begin{array}{c}\text { yes } \\
\text { no }\end{array}$ & $\begin{array}{l}10 \\
95\end{array}$ & $\begin{array}{l}2 \\
7\end{array}$ & 0.53 \\
\hline The presence of allergic diseases in close relatives & $\begin{array}{c}\text { yes } \\
\text { no }\end{array}$ & $\begin{array}{l}10 \\
95\end{array}$ & $\begin{array}{l}2 \\
7\end{array}$ & 0.53 \\
\hline Acute respiratory diseases in the anamnesis $-1-2$ times a year & $\begin{array}{c}\text { yes } \\
\text { no }\end{array}$ & $\begin{array}{l}72 \\
33\end{array}$ & $\begin{array}{l}5 \\
4\end{array}$ & 0.67 \\
\hline Pertussis & $\begin{array}{c}\text { yes } \\
\text { no }\end{array}$ & $\begin{array}{c}5 \\
100\end{array}$ & $\begin{array}{l}2 \\
7\end{array}$ & 0.17 \\
\hline Scarlet fever & $\begin{array}{c}\text { yes } \\
\text { no }\end{array}$ & $\begin{array}{c}1 \\
104\end{array}$ & $\begin{array}{l}1 \\
8\end{array}$ & 0.37 \\
\hline Rubeola & $\begin{array}{c}\text { yes } \\
\text { no }\end{array}$ & $\begin{array}{l}26 \\
79\end{array}$ & $\begin{array}{l}3 \\
6\end{array}$ & 0.87 \\
\hline Measles & $\begin{array}{c}\text { yes } \\
\text { no }\end{array}$ & $\begin{array}{c}9 \\
96\end{array}$ & $\begin{array}{l}1 \\
8\end{array}$ & 0.72 \\
\hline
\end{tabular}


Проблеми екології та медицини

\begin{tabular}{|c|c|c|c|c|}
\hline \multicolumn{2}{|c|}{ The presence of the sign } & \multirow{2}{*}{$\begin{array}{c}\begin{array}{c}\text { Carriers of } A A \\
\text { genotype } \\
(\mathrm{n}=105)\end{array} \\
57 \\
48\end{array}$} & \multirow{2}{*}{$\begin{array}{c}\begin{array}{c}\text { Carriers of } A G \\
\text { genotype } \\
(\mathrm{n}=9)\end{array} \\
7 \\
2 \\
\end{array}$} & \multirow{2}{*}{$\begin{array}{c}\mathrm{p}^{*} \\
0.31\end{array}$} \\
\hline Chicken pox & $\begin{array}{c}\text { yes } \\
\text { no }\end{array}$ & & & \\
\hline Parotitis & $\begin{array}{c}\text { yes } \\
\text { no }\end{array}$ & $\begin{array}{c}5 \\
100 \\
\end{array}$ & $\begin{array}{l}2 \\
7 \\
\end{array}$ & 0.17 \\
\hline Infectious hepatitis & $\begin{array}{c}\text { yes } \\
\text { no } \\
\end{array}$ & $\begin{array}{c}2 \\
103 \\
\end{array}$ & $\begin{array}{l}1 \\
8 \\
\end{array}$ & 0.57 \\
\hline Skin viral (herpetic) infections & $\begin{array}{l}\text { yes } \\
\text { no }\end{array}$ & $\begin{array}{l}11 \\
94\end{array}$ & $\begin{array}{l}1 \\
8\end{array}$ & 0.61 \\
\hline Infections of the gastrointestinal tract & $\begin{array}{c}\text { yes } \\
\text { no } \\
\end{array}$ & $\begin{array}{c}9 \\
96 \\
\end{array}$ & $\begin{array}{l}1 \\
8 \\
\end{array}$ & 0.72 \\
\hline Urogenital infections & $\begin{array}{c}\text { yes } \\
\text { no }\end{array}$ & $\begin{array}{c}1 \\
104 \\
\end{array}$ & $\begin{array}{l}1 \\
8 \\
\end{array}$ & 0.37 \\
\hline Neuroinfections & $\begin{array}{c}\text { yes } \\
\text { no } \\
\end{array}$ & $\begin{array}{c}0 \\
105 \\
\end{array}$ & $\begin{array}{l}1 \\
8 \\
\end{array}$ & 0.12 \\
\hline Hives & $\begin{array}{c}\text { yes } \\
\text { no }\end{array}$ & $\begin{array}{c}4 \\
101 \\
\end{array}$ & $\begin{array}{l}2 \\
7 \\
\end{array}$ & 0.11 \\
\hline Cystitis & $\begin{array}{c}\text { yes } \\
\text { no }\end{array}$ & $\begin{array}{c}8 \\
97 \\
\end{array}$ & $\begin{array}{l}1 \\
8\end{array}$ & 0.79 \\
\hline
\end{tabular}

As can be seen from Table 3, no reliable association was found between the presence of the $G$ allele in the genotype (carriers of the AG genotype) of the polymorphic variant of the TLR4 gene (rs4986790) and data, reported during the interviewing and listed in the table.

The presence of individual clinical manifestations in individuals who are carriers of another polymorphic vari- ant of the TLR4 gene (rs4986791) has been analyzed. Since only one person had the homozygous TT genotype, we combined the carriers of this genotype with carriers of the heterozygous CT genotype. Thus, the number of individuals carrying the polymorphic allele $T$ was 11 (Table 4). Analysis of clinical signs in the presence of polymorphic variant of the TLR4 gene (rs4986791) in the genotype

\begin{tabular}{|c|c|c|c|c|}
\hline \multicolumn{2}{|l|}{ The presence of the sign } & \multirow{2}{*}{$\begin{array}{c}\text { Carriers of CC } \\
\text { genotype }(\mathrm{n}= \\
103) \\
29 \\
74\end{array}$} & \multirow{2}{*}{$\begin{array}{c}\text { Carriers of the } \\
\text { Tallele (CT } \\
\text { and TT } \\
\text { genotypes) } \\
(\mathrm{n}=11) \\
4 \\
7\end{array}$} & \multirow{2}{*}{$\begin{array}{c}p^{*} \\
0.83\end{array}$} \\
\hline A bad habit of smoking & $\begin{array}{l}\text { Yes } \\
\text { no }\end{array}$ & & & \\
\hline Acute respiratory diseases in the anamnesis $-1-2$ times a year & $\begin{array}{l}\text { Yes } \\
\text { no }\end{array}$ & $\begin{array}{l}69 \\
34 \\
\end{array}$ & $\begin{array}{l}8 \\
3 \\
\end{array}$ & 0.96 \\
\hline Pertussis & $\begin{array}{c}\text { Yes } \\
\text { no }\end{array}$ & $\begin{array}{c}6 \\
97\end{array}$ & $\begin{array}{c}1 \\
10 \\
\end{array}$ & 0.82 \\
\hline Rubeola & $\begin{array}{l}\text { Yes } \\
\text { no }\end{array}$ & $\begin{array}{l}27 \\
76\end{array}$ & $\begin{array}{l}2 \\
9 \\
\end{array}$ & 0.83 \\
\hline Chicken pox & $\begin{array}{l}\text { Yes } \\
\text { no }\end{array}$ & $\begin{array}{l}57 \\
46\end{array}$ & $\begin{array}{l}7 \\
4\end{array}$ & 0.84 \\
\hline Infectious hepatitis & $\begin{array}{l}\text { Yes } \\
\text { no }\end{array}$ & $\begin{array}{c}2 \\
101\end{array}$ & $\begin{array}{c}1 \\
10\end{array}$ & 0.68 \\
\hline Skin fungal infections & $\begin{array}{c}\text { Yes } \\
\text { no }\end{array}$ & $\begin{array}{c}7 \\
96\end{array}$ & $\begin{array}{c}1 \\
10\end{array}$ & 0.74 \\
\hline Rheumatism & $\begin{array}{c}\text { Yes } \\
\text { no }\end{array}$ & $\begin{array}{c}1 \\
102\end{array}$ & $\begin{array}{c}1 \\
10\end{array}$ & 0.46 \\
\hline Hives & $\begin{array}{c}\text { Yes } \\
\text { no }\end{array}$ & $\begin{array}{c}5 \\
98\end{array}$ & $\begin{array}{c}1 \\
10\end{array}$ & 0.91 \\
\hline Cystitis & $\begin{array}{c}\text { yes } \\
\text { no }\end{array}$ & $\begin{array}{c}7 \\
96\end{array}$ & $\begin{array}{l}2 \\
9\end{array}$ & 0.46 \\
\hline Pyelonephritis & $\begin{array}{l}\text { Yes } \\
\text { no }\end{array}$ & $\begin{array}{c}1 \\
102\end{array}$ & $\begin{array}{c}1 \\
10\end{array}$ & 0.46 \\
\hline
\end{tabular}

A comparative analysis of the presence of the allele $T$ in the genotype (CT and TT genotypes) of the TLR4 gene (rs4986791) with definite clinical manifestations of individual diseases did not reveal any reliable association.

Thus, the result of the conducted study of the presence of association in the genotypes of polymorphous variants of the TLR2 (rs5743708), TLR4 (rs4986790, rs4986791) genes with a general somatic state was the detection of a reliable link between the presence of the $A$ allele in the genotype of the polymorphic variant of the TLR2 gene (rs5743708) with rheumatism ( $p=0.05)$, pyelonephritis $(p=0.05)$, and a bad habit of smoking $(p=$ 0.04).

\section{References}

1. Takeda K. Toll-Like Receptors / K. Takeda, S. Akira // Current protocols in immunology. - 2015. - Vol. 109, Issue 1. - P. 14.12.1-14.12.10. 
ToM 22, N 1-2 2018 p.

2. Receptors of congenital immunity: approaches to quantitative and functional evaluation of Toll-like human receptors / L.V. Kovalchuk, M.V. Khorev, A.S. Varivoda [and others] // Immunology. - 2008. - № 4. - P. 223-227.

3. Toll-like receptor 4 gene (TLR4), but not TLR2, polymorphisms modify the risk of tonsillar disease due to Streptococcus pyogenes and Haemophilus influenzae / Liadaki K., Petinaki E., Skoulakis C. [et al.] // Clin. Vaccine Immunol. - 2011. - Vol. 18, N. 2. - P. 217-222.

4. TLR4 896A/G gene polymorphism, rather than the TLR4 $1196 \mathrm{C} / \mathrm{T}$ and TLR2 2258G/A gene polymorphisms, determines the severe and aggravated course of atopic dermatitis in children / L.Yu. Levchenko, O.V. Izmailova, O.A. Shlykova, I.P. Kaidashev // Cytology and Genetics. 2013. - Vol. 47, № 3. - P. 46-53.

5. The role of polymorphisms of Toll-like receptors genes 2, 4 and Clara cells in the development of bronchial asthma in adults / N.V. Lyakhovskaya, O.V. Izmailova, O.A. Shlykova, I.P. Kaidashev // Problems of ecology and medicine. - 2013. - Vol. 17, № 5-6. - P. 71-75.

6. Relationship of TLR2 and TLR4 gene polymorphism with a penchant for individual urogenital infections / Izmaĭlova O.V., Shlykova O.A., Bobrova N.O., Kaĭdashev I.P. // Tsitol Genet. - 2011. - Vol. 45, № 4. - P. 29-35.

7. . 2011 Sep-Oct;(5):83-6.

8. Role of several periodontopathogenic microorganisms and tlr4 gene Asp299Gly polymorphism in atherosclerosis pathogenesis / Skochko O.V., Bobrova N.A., Izmaylova O.V, Kaĭdashev I.P. // Zh Mikrobiol Epidemiol Immunobiol. -2011 . - № 5. - P. 83-86.

9. Sakevich V.D. The prevalence of haplotypes of TLR2, TLR4, CLC-10 polymorphic genes and their association with individual immunological parameters in patients with allergic rhinitis / V.D. Sakevich // Problems of ecology and medicine. - 2013. - Vol. 17, № 5-6. - P. 16-23.

10. Different patterns of Toll-like receptor 2 polymorphisms in populations of various ethnic and geographic origins / $\mathrm{M}$. loana, B. Ferwerda, T.S. Plantinga [et all.] // Infect. Immun. - 2012. - Vol. 80, No. 5. - P. 1917-1922.
11. Genetic factors (genes of receptors of congenital immunity - TLRs) in the pathogenesis of atherosclerosis and its complications / I.I. Zhidkova, A.V. Ponasenko, M.V. Khutornaya [et al] // Medical immunology. - 2017. - T. 19, № 3. - P. 241-254.

12. TLR4 polymorphisms and ageing: implications for the pathophysiology of age-related diseases / C.R. Balistreri, G. Colonna-Romano, D. Lio, [et al.] // J. Clin. Immunol. 2009. - Vol. 29. - P. 406-415.

13. The Toll-like receptor 4 (Asp299Gly) polymorphism is a risk factor for gram-negative and haematogenous osteomyelitis / A.H. Montes, V. Asensi, V. Alvarez [et al.] // J. Clin. Exp. Immunol. - 2006. - Vol. 143 (3). - P. 404-413.

14. Erridge C. Monocytes heterozygous for the Asp299Gly and Thr399lle mutations in the Toll-like receptor 4 gene show no deficit in lipopolysaccharide signalling / C. Erridge, J. Stewart, I.R. Poxton // J. Exp. Med. - 2003. - Vol. 197 (12). - P.1787-1791.

15. Mode of access to the website: https://www.ncbi.nlm.nih.gov/snp/?term=TLR2.

16. Mode of access to the website:

https://www.ensembl.org/Homo_sapiens/Variation/Populati on? $\mathrm{db}=$ core; $r=4: 153704665$ -

153705665; $=$ =rs 5743708; vdb=variation; vf=3234468\#popul ation_freq_EUR.

17. Asp299Gly Polymorphism of the TLR-4 Gene in Adult Patients with Fixed and with Reversible Airflow Obstruction in the Population of Crimea, Ukraine / Yu. Bisyuk, A. Kurchenko, O. Akhtemiichuk [et al.] // J. of Allergy and Clin. Immunol. - 2017. - Vol. 139 (2). - P. AB198.

18. Mode of access to the website: https://www.ncbi.nlm.nih.gov/snp/?term=TLR4.

19. Mode of access to the website: https://www.ensembl.org/Homo_sapiens/Variation/Populati on? $\mathrm{db}=$ core; $r=9: 117712524$ $117713524 ; \mathrm{v}=\mathrm{rs} 4986790 ; \mathrm{vdb}=$ variation; $\mathrm{vf}=3210403$.

20. Mode of access to the website: https://www.ensembl.org/Homo_sapiens/Variation/Populati on? $\mathrm{db}=$ core; $\mathrm{r}=9: 117712824$ -

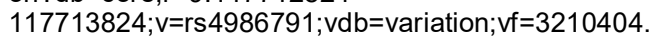

